\title{
Range Extension and Geographic Distribution Record for the Burmese Python, Python bivittatus Kuhl 1820 (Reptilia: Pythonidae) in Northwestern India
}

\author{
Ritesh Joshi ${ }^{1}$ and Abhishek Singh ${ }^{2}$
}

${ }^{1}$ Conservation \& Survey Division, Ministry of Environment, Forest \& Climate Change, New Delhi, India (ritesh_joshi2325@yahoo.com) ${ }^{2}$ Endangered Flora and Fauna on Earth Conservation Team, VasantVihar, Dehradun, Uttarakhand, India (ngoeffect@gmail.com)

Snakes in the family Pythonidae include some of the

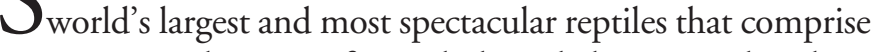
an enormous diversity of morphology, behavior, and ecology (Reynolds et al. 2014). The Indian Subcontinent is home to three species of pythons, the Indian Python (Python molurus Linnaeus 1758), the Burmese Python (P. bivittatus Kuhl 1820), and the Reticulated Python (Malayopython reticulatus Schneider 1801). Until recently, the Burmese Python was considered a subspecies of the Indian Python (e.g., Smith 1943; Daniel 1983; O’Shea 1998; Whitaker and Captain 2004) but the two taxa now are considered distinct species (Jacobs et al. 2009; Reynolds et al. 2014; Barker et al. 2015). The Reticulated Python previously was assigned to the genus Python but was reassigned to Malayopython by Auliya et al. (2002) and Reynolds et al. (2014).

Bhupathy (1995) provided an overview of the distribution of the latter two species in India, which revealed that

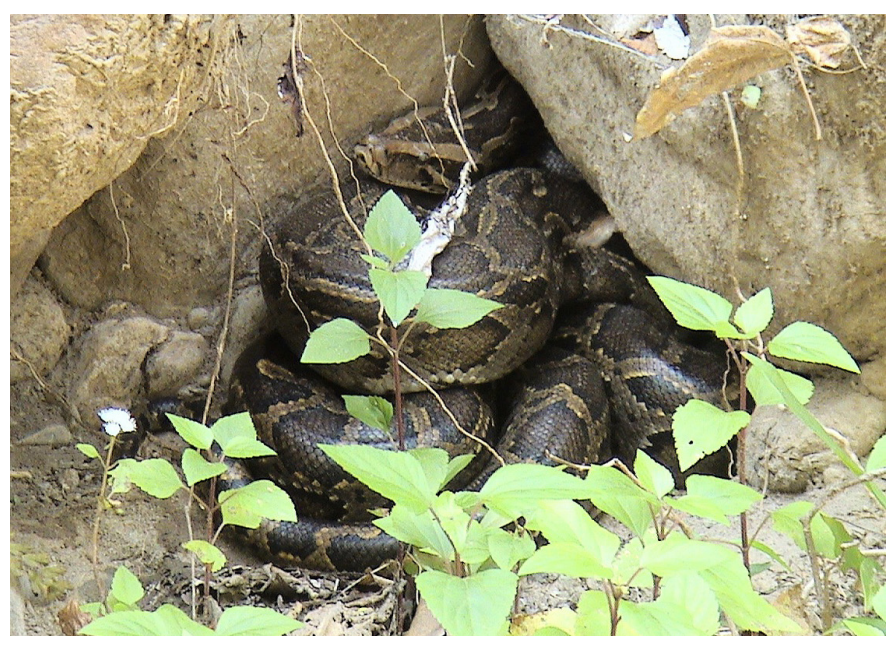

Fig. 1. Burmese Python (Python bivittatus) in a rock crevice in the Khara Forest of the Chilla Forest Range of the Rajaji National Park. Photograph by Ritesh Joshi.

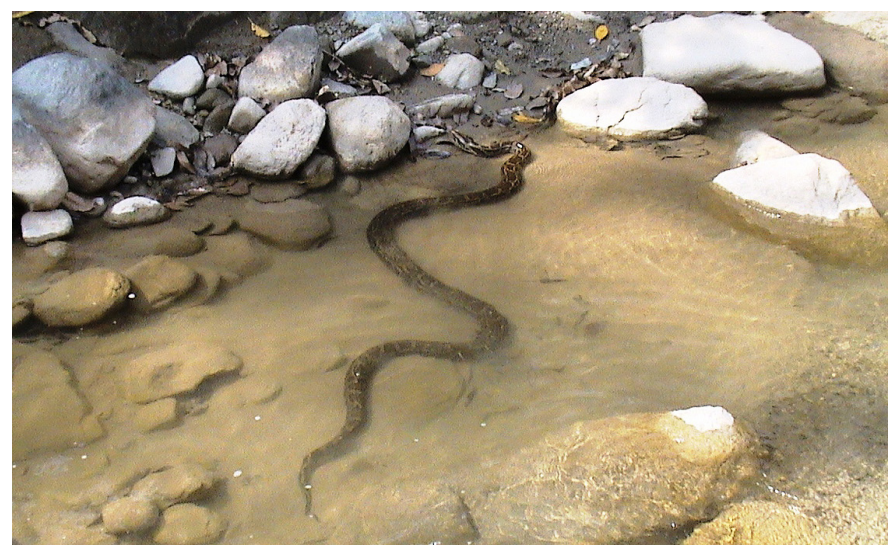

Fig. 2. Burmese Python (Python bivittatus) in the Mitthawali River flowing in the Chilla Forest of Rajaji National Park. Photograph by Ritesh Joshi.

the Burmese Python, which is a Malayan faunal element, has a wide distribution in northeastern India. That study also revealed that the species is distributed along the Himalayan foothills, which include part of the Rajaji National Park (RNP), the terai (a belt of marshy grasslands, savannas, and forests located south of the outer foothills of the Himalayas, the Shivalik Hills, an area north of the Indo-Gangetic Plain of the Ganges, the Brahmaputra, and their tributaries), and the mangroves of the eastern coast at least as far as the Bhitarkanika Wildlife Sanctuary in India (the MahanadiBrahmani-Baitarani Delta).

The Indian Python is widely distributed in peninsular India from Sind in the northwest to Bengal in the northeast, whereas the Burmese Python occurs in the Indo-Chinese Subregion, southern China, Hong Kong, and Hainan (Smith 1943). Precise information on the distribution of the Burmese Python in India is not available except for the Indo-Chinese Subregion (i.e., parts of northeastern India; Daniel 1983; Bhupathy 1995). These species differ morphologically in that 


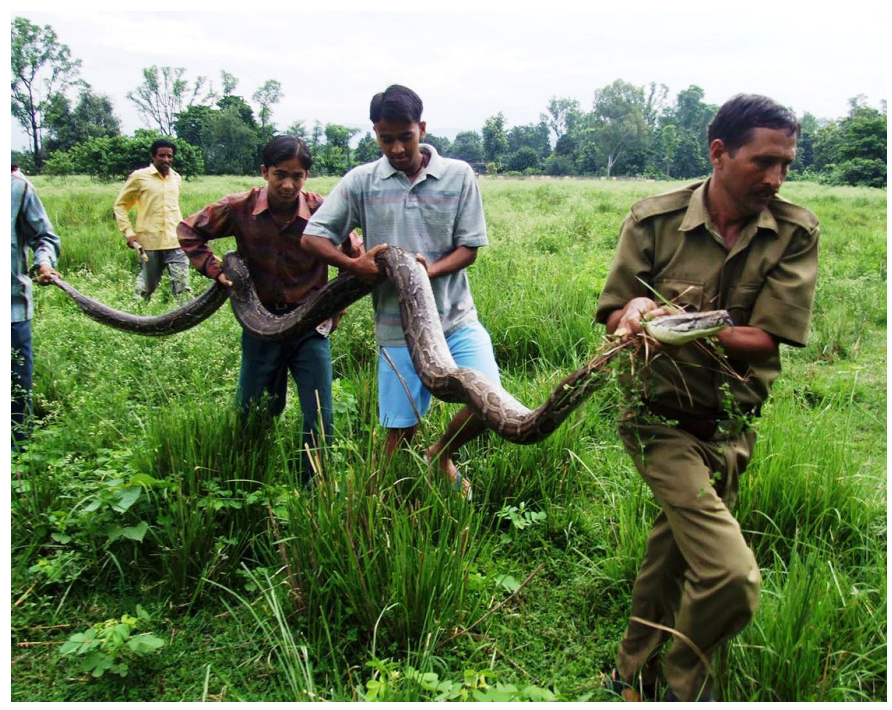

Fig. 3. The largest Burmese Python (Python bivittatus; $-3.5 \mathrm{~m}$ ) recorded from the Chilla Forest of Rajaji National Park. Photograph by Raju Pushola.

in Indian Pythons, the sixth or seventh labial contacts the eye, a lance-shaped mark on top of the head is indistinct in adults, and the tongue is pink; whereas in Burmese Pythons the labials are separated from the eye by suboculars, the lance-shaped mark on the head is distinct, and the tongue is blue-black (Smith 1943; Daniel 2002; O'Shea 1998; Whitaker and Captain 2004; Jacobs et al. 2009).

Inventories conducted by the Zoological Survey of India (ZSI) during 1995 and 2008 in RNP and the Corbett Tiger Reserve (CTR) corroborated the presence of the Indian Python in these protected habitats (Husain and Tilak 1995; Bahuguna 2008). Subsequently, Bahuguna (2010) stated that the Indian Python occurs in RNP and parts of CTR (Bahuguna 2010). After the first report of Burmese Pythons in RNP by Bhupathy (1995), Whitaker and Captain (2004), Nawab and Srivastava (2008), Sondhi (2010), and Das et al. (2012) noted the occurrence of the species in that area. O'Shea (1998) opined that the terai forests of the southern Himalayas provide a corridor of suitable habitat that allows species from the Indo-Chinese Subregion to spread across the north of the Indian Subregion and the tributaries of the Gangetic River System before being channeled southward into the flood plains of Uttar Pradesh. In Bangladesh, eastern India, West Bengal, Orissa, and west along the southern Nepalese border to Uttarakhand, Burmese Pythons are sympatric and in some places synoptic with Indian Pythons (Barker and Barker 2008).

Details regarding the distributions of Indian and Burmese Pythons in the area remain elusive. In this report, we confirm the occurrence of the Burmese Python in RNP and adjoining habitats two decades since the first report and provide the first authenticated record of the species in the District of Dehradun. RNP and the Dehradun Forest Division
(DFD) are located in northwestern India at $29^{\circ} 15^{\prime}-30^{\circ} 31^{\prime} \mathrm{N}$, $77^{\circ} 52^{\prime}-78^{\circ} 22^{\prime} \mathrm{E}$ and $30^{\circ} 2^{\prime}-31^{\circ} 26^{\prime} \mathrm{N}, 77^{\circ} 52^{\prime}-78^{\circ} 19^{\prime} \mathrm{E}$, and fall in the Gangetic Plains Biogeographic Zone and the Upper Gangetic Plains Province. The largest portion of RNP is in Shivalik's Biogeographic Subdivision, which constitutes an important repository of reptilian fauna.

Distinguishing Indian and Burmese Pythons in the field can be difficult, since diagnostic characters cannot always be seen when animals are moving, high in a tree, or in refugia. Consequently, we randomly collected photographic evidence in 2006-2010 to document the presence of both species in the Chilla Forest of the RNP and adjoining protected areas. Both species were identified based on descriptions in Smith (1943), Daniel (1983), O'Shea (1998), Whitaker and Captain (2004), and Jacobs et al. (2009). We also consulted forest officials, local people, and the Gujjar nomadic community residing both in and outside the park area.

On 31 March 2007, a Burmese Python of unknown sex was recorded resting in a rock crevice in the Khara Forest of the Chilla Forest Range of the RNP $\left(29^{\circ} 53^{\prime} 50.5 \mathrm{~N}\right.$, $78^{\circ} 16^{\prime} 47.8$ E; Figs. 1-2). On 9 August 2007, an individual was observed in the Chilla Forest near the Haridwar-ChillaRishikesh Road; this snake was rescued and relocated inside the forest $\left(29^{\circ} 58^{\prime} 15.6 \mathrm{~N}, 78^{\circ} 12^{\prime} 41.8 \mathrm{E}\right.$; Fig. 3). Another individual was sighted shortly thereafter near the Haridwar Forest Range of the RNP (29 $56^{\prime} 23$ N, 78 $7^{\circ} 23$ E; Fig. 4). Three additional observations of Burmese Pythons were made in the DFD. On 15 September 2010, an individual Burmese Python was observed near the Canal Road along the Rispna River near Jakhan $\left(30^{\circ} 21^{\prime} 57.7 \mathrm{~N}, 78^{\circ} 04^{\prime} 38.7 \mathrm{E}\right)$. Subsequently, on 14 October 2011 and 8 November 2011, adults were observed in the Timli Forest Range of the Kalsi Forest Division $\left(30^{\circ} 20^{\prime}-30^{\circ} 25^{\prime} \mathrm{N}, 7^{\circ} 40^{\prime}-77^{\circ} 45^{\prime} \mathrm{E}\right.$; Figs. $5-6)$ and in the Lacchiwala Forest Range (30 $15^{\prime} 19.1 \mathrm{~N}$, $78^{\circ} 01^{\prime} 55.8 \mathrm{E}$; Fig. 7). Most sightings occurred during the summer monsoon season near natural water sources, in grasslands, and in the riparian corridors of the Ganges.

Both the available literature and our field observations indicate that both Indian and Burmese Pythons occur in parts

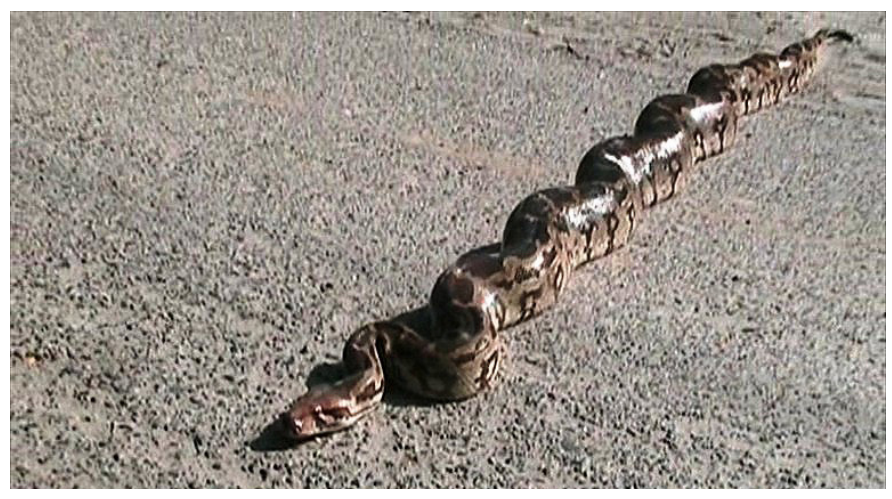

Fig. 4. A Burmese Python (Python bivittatus) near the Haridwar Forest Range of Rajaji National Park. Photograph by Swarup Puri/Sunil Pal. 
of the upper Gangetic Plains. Observations also reveal that various protected areas in the upper Gangetic Plains Province provide suitable habitat for pythons in the tropical moist deciduous forest of northwestern India, with the Ganges and the extensive network of seasonal rivers contributing to the survival and dispersal of both species. Frequent sightings of pythons also suggest that python populations are increasing in the region.

\section{Conservation Concerns}

In the monsoon season, pythons, especially juveniles, were encountered frequently outside protected areas and in and around the human settlements. We attribute this mainly to the movement of individuals along the flooding tributaries of the Ganges. Rescuing snakes from public areas and releasing them into forested area is a common occurrence. Unfortunately, human-python encounters also can lead to the unnatural deaths of pythons. We noted during field surveys that many local people are unaware that pythons are not venomous, which also leads to the non-participation of the local community in conservation initiatives.

The genus Python is listed in Schedule I of the Indian Wildlife (Protection) Act of 1972 (Anonymous 2003). The Burmese Python is categorized as Vulnerable in the IUCN Red List of Threatened Species (Stuart et al. 2012), but the Indian Python has not been assessed. In contrast, both species are considered as Lower Risk-Near Threatened in the conservation assessment of the reptilian fauna of India (Molur and

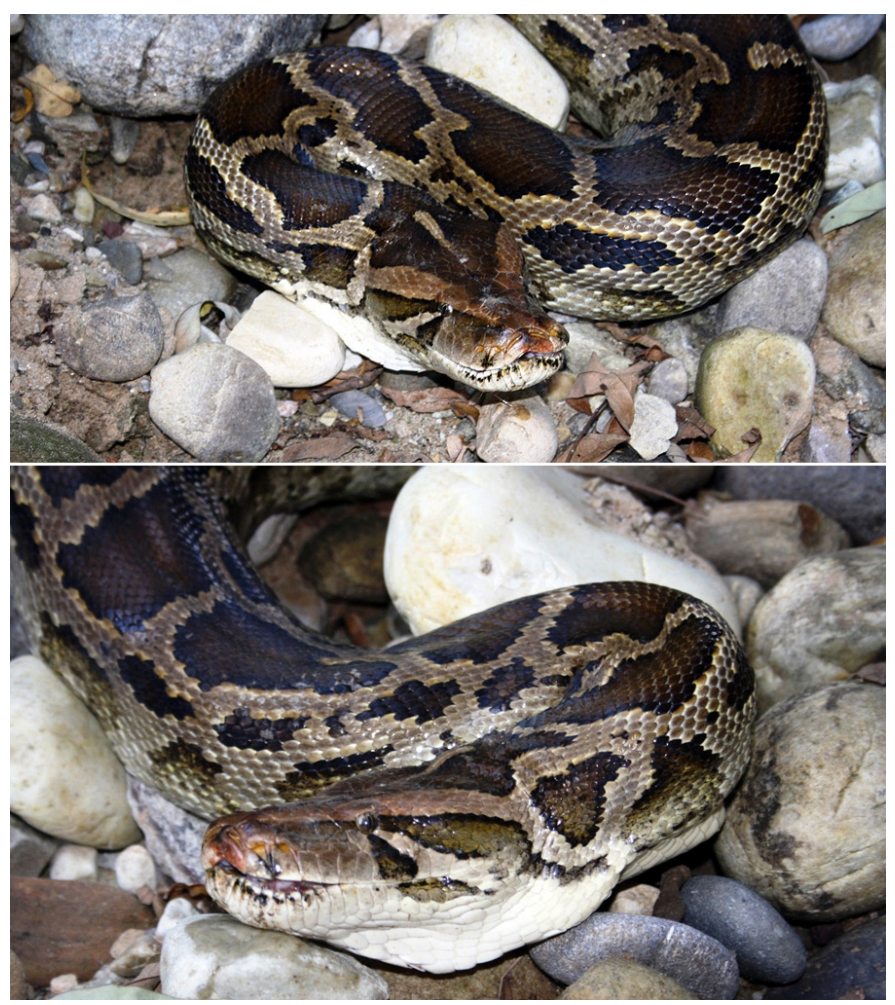

Fig. 5. A Burmese Python (Python bivittatus) in the Timli Forest Range of the Kalsi Forest Division. Photograph by Abhishek Singh.

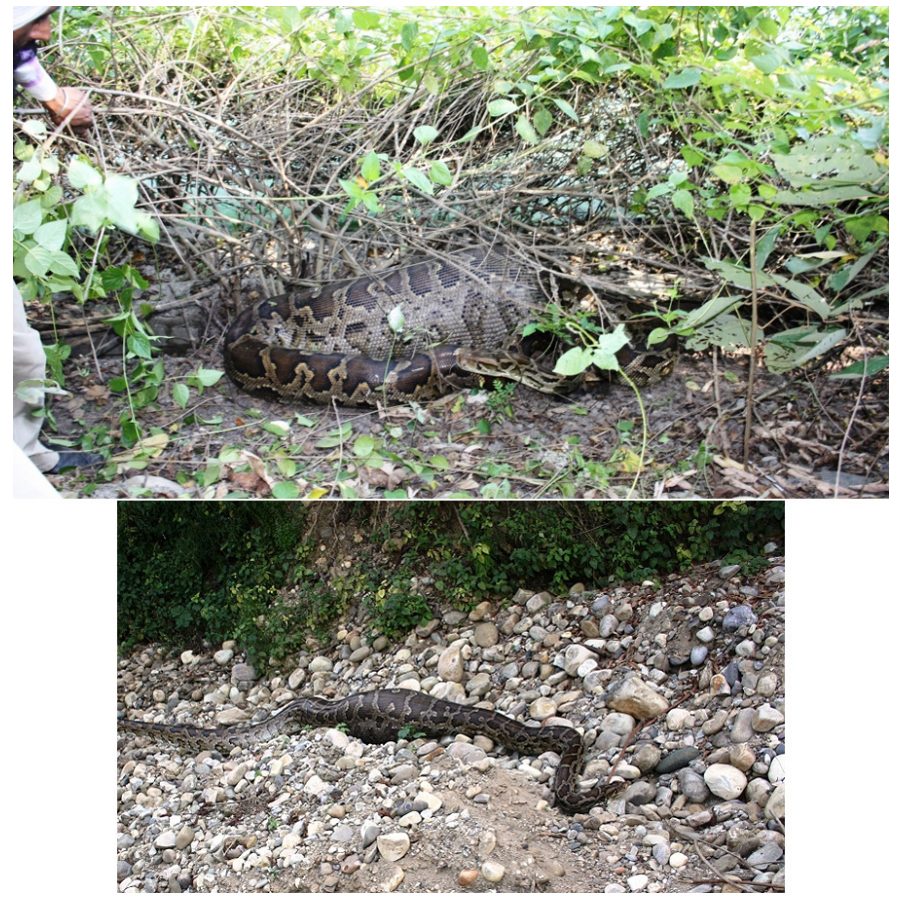

Fig. 6. A Burmese Python (Python bivittatus) after swallowing a goat and being released in the Timli Forest Range of the Kalsi Forest Division. Photographs by Abhishek Singh.

Walker 1998). Increasing development and anthropogenic activities across the riparian corridors of the Ganges, shrinkage of natural water sources inside protected areas, expansion of the road network across a long chain of protected habitats, and lack of awareness among the local people regarding the nature of pythons were some of the observed threats.

This report represents a small northward expansion of the known range of the Burmese Python, including its presence in the CTR. Bhupathy (1995) indicated that the known northwestern and southeastern extent of the species' distribution are the RNP in Uttarakhand and the Bhitarkanika Wildlife Sanctuary in Orissa, respectively; however, the precise limits have not been determined nor have any specific studies targeted the species.

Barker and Barker (2008) indicated that the existence of the Burmese Python in various disjunct localities in the foothills of the Himalayas along the Indian-Nepalese border suggests that the range of the species might extend west along the Ganges, north along the Gandak River to the vicinity of Chitwan, and northwest along the Ghaghara River and its tributaries that drain south-western Nepal and eastern Uttarakhand. Furthermore, the protected areas that fall within the Upper Gangetic Plains might serve as a hub for the species in the northwestern Shivalik Landscape. We are uncertain whether populations of either the Indian or the Burmese Python are increasing, stable, or decreasing, nor can we even speculate about the possible ecological consequences of populations of one species increasing, potentially at the expense of the other. Consequently, long-term field observa- 


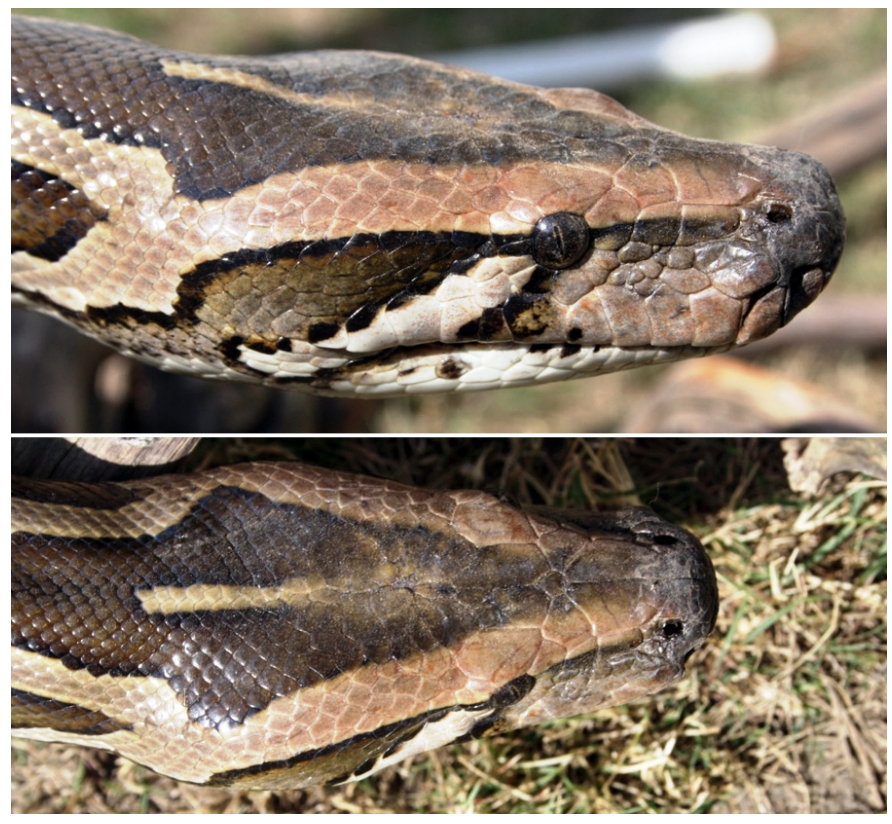

Fig. 7. Enlarged view of the head and eye scalation of a Burmese Python (Python bivittatus) from the Lacchiwala Forest Range of the Dehradun Forest Division. Photograph by Abhishek Singh.

tions and detailed habitat surveys are required. We strongly recommend that a pilot study be initiated to evaluate the habitats and status of both species; this is essential for developing management plans for pythons in northwestern India.

\section{Acknowledgements}

We thank Mr. Romulus Whitaker, Herpetologist \& Conservationist, Chennai Snake Park Trust, for confirming the identification of snakes from photographs. The first author also thanks the G.B. Pant Institute of Himalayan Environment \& Development, Garhwal Unit, SrinagarGarhwal, Uttarakhand, India, and the Doon Institute of Management \& Research, Rishikesh, Uttarakhand, India, the institutions with which he was associated during the study period, and acknowledges the Uttarakhand Forest Department for providing permission to conduct research on elephant ecology and behavior. We dedicate this article to the late Dr. S. Bhupathy, the renowned herpetologist, who contributed significantly to Indian herpetology and our knowledge of python ecology in India.

\section{Literature Cited}

Anonymous. 2003. Wildlife (Protection) Act, 1972 [as amended in 2003]. Wildlife Trust of India, Natraj Publishers, Dehradun.

Auliya, M., P. Mausfeld, A. Schmitz, and W. Böhme. 2002. Review of the Reticulated Python (Python reticulatus Schneider, 1801) with the description of new subspecies from Indonesia. Naturwissenschaften 89:201-213.

Bahuguna, A. 2008. Reptilia, pp. 143-157. In: Director, Zoological Survey of India (ed.), Fauna of Corbett Tiger Reserve. Conservation Area Series 35. Zoological Survey of India, India.

Bahuguna, A. 2010. Reptilia, pp. 445-503. In: Director, Zoological Survey of India (ed.), Fauna of Uttarakhand. State Fauna Series, 18 (Part I). Zoological Survey of India, India.

Barker, D.G. and T.M. Barker. 2008. The distribution of the Burmese Python, Python molurus bivittatus. Bulletin of the Chicago Herpetological Society 43(3):33-38.

Barker, D.G., T.M. Barker, M.A. Davis, and G.W. Schuett. 2015. A review of the systematics and taxonomy of Pythonidae: An ancient serpent lineage. Zoological Journal of the Linnean Society 175:1-19.

Bhupathy, S. 1995. Distribution of Python molurus bivittatus in India. Cobra 21:2-5.

Daniel, J.C. 1983. The Book of Indian Reptiles. Bombay Natural History Society, Bombay, India.

Das, A., D. Basu, L. Converse, and S.C. Choudhury. 2012. Herpetofauna of Katerniaghat Wildlife Sanctuary, Uttar Pradesh, India. Journal of Threatened Taxa 4:2553-2568.

Husain, A. and R. Tilak. 1994. Snakes (Reptilia: Serpentes), pp. 91-113. In: Director, Zoological Survey of India (ed.), Fauna of Conservation Area 5: Fauna of Rajaji National Park. Zoological Survey of India, Kolkata.

Jacobs, H.J., M. Auliya and W. Böhme. 2009. Zur Taxonomie des dunklen Tigerpythons, Python molurus bivittatus Kuhl, 1820, speziell der Population von Sulawesi. Sauria 31(3):5-16.

Molur, S. and S. Walker. 1998. Report of the workshop 'Conservation Assessment and Management Plan for Reptiles of India' (BCPP-Endangered Species Project), Zoo Outreach Organisation, Conservation Breeding Specialist Group, Coimbatore, India (http://zooreach.org).

Nawab, A. and A. Srivastava. 2008. Record of Burmese Python Python molurus bivittatus and its conservation status in Corbett Tiger Reserve, Uttarakhand, India. Journal of the Bombay Natural History Society 105(1):100-101.

O'Shea, M. 1998. Herpetological results of two short field excursions to the Royal Bardia region of western Nepal, including range extensions for Assamese/ Indo-Chinese snake taxa, pp. 306-317. In: A. de Silva (ed.), Biology and Conservation of the Amphibians, Reptiles and their Habitats in South Asia. Amphibian and Reptile Research Organisation of Sri Lanka, Peradenya.

Reynolds, R.G., M.L. Niemiller, and L.J. Revell. 2014. Toward a tree-of-life for the boas and pythons: Multilocus species-level phylogeny with unprecedented taxon sampling. Molecular Phylogenetics and Evolution 71: 201-213.

Smith, M.A. 1943. The Fauna of British India, Ceylon and Burma including the Whole of the Indo-Chinese Sub-region. Reptilia and Amphibia Vol. III. Serpents. Taylor and Francis, London.

Sondhi, S. 2010. The Gigantic Burmese Python. Doon Watch Nature Series for Dehradun Live, Hindustan Times (http://www.kalpavriksh.org).

Stuart, B., T.Q. Nguyen, N. Thy, L.Grismer, T. Chan-Ard, D. Iskandar, E. Golynsky, and M.W.N. Lau. 2012. Python bivittatus. The IUCN Red List of Threatened Species. Version 2015.2 (www.iucnredlist.org).

Whitaker, R. and A. Captain. 2004. Snakes of India. The Field Guide. Draco Books, Chennai, India. 